\title{
Trend of Growing Season Characteristics of Semi-Arid Arusha District in Tanzania
}

\author{
Nganga I. Kihupi ${ }^{1}$, Andrew K. P. R. Tarimo ${ }^{1}$, Richard J. Masika ${ }^{2}$, Brian Boman ${ }^{3} \&$ Warren A. Dick ${ }^{4}$ \\ ${ }^{1}$ Department of Agricultural Engineering \& Land Planning, Sokoine University of Agriculture, Morogoro, \\ Tanzania \\ ${ }^{2}$ Arusha Technical College, Arusha, Tanzania \\ ${ }^{3}$ Indian River Research and Education Center, University of Florida, Fort Pierce, FL, USA \\ ${ }^{4}$ School of Environment and Natural Resources, The Ohio State University, Wooster, OH, USA \\ Correspondence: Nganga I. Kihupi, Department of Agricultural Engineering \& Land Planning, Sokoine \\ University of Agriculture, P.O. Box 3003, Chuo Kikuu, Morogoro, Tanzania. Tel: 255-786-796-963. E-mail: \\ nikihupi@yahoo.com
}

Received: May 30, 2015 Accepted: July 2, 2015 Online Published: August 15, 2015

doi:10.5539/jas.v7n9p45 URL: http://dx.doi.org/10.5539/jas.v7n9p45

\begin{abstract}
The timing and distribution of rainfall determine both the length and quality of the growing season, and hence have important implications for agricultural production and food security. Using over 50 years of climatic data for Arusha District in Tanzania, the paper presents an analysis of growing season characteristics and other meteorological variables. Results indicate that the climate of Arusha District and Oljoro in particular is changing. Both the length of the growing season and number of wet days within the season are showing a decreasing trend as rains appear to be starting later than they used to in the past. Other meteorological variables such as temperature, wind speed and reference evapotranspiration are showing an increasing trend. Changes in land use/cover in and around the study area in the 1970s through 1990s due to expansion of agricultural land and population pressure would seem to have fuelled the observed changes in the growing season characteristics. This does not augur well for rain-fed agriculture and thus judicial use of scarce water resources including rainwater harvesting would seem to be a viable option for sustainable agricultural production.
\end{abstract}

Keywords: growing season characteristics, climate change, semi-arid, Arusha District

\section{Introduction}

Rainfall plays a central role in agricultural production and water supply in much of sub-Saharan Africa. However total dependence on rainfall faces many risks related to climatic variability (O'Brien \& Vogel, 2003). Variability in climate, unwelcome as it may be, is inevitable and part and parcel of evolution (Unganai, 1993). Reliability of rainfall particularly at critical phases of crop development can explain much of the variation in agricultural potential of tropical regions especially the semi-arid tropics. Over half of Tanzania's land area can be described as semi-arid with limited and erratic rains (Kihupi, Tarimo, \& Dihenga, 2007). Climatic variability on the seasonal-to-interannual time scale affects many facets of human life including food security and livelihoods. The climate of the semi-arid tropics is thus a primary constraint on agricultural development (Kanemasu, Stewart, Van Donk, \& Virmani, 1990).

The most important questions about rainfall from the farmer's point of view are concerned with the onset, cessation and length of the rainy season including the risk of dry spells within the growing season. These constitute the so-called growing season characteristics. The timing and distribution of rainfall determine both the length and quality of the growing season, and hence have important implications for agricultural production and food security. The quality of a growing season is determined to a large extent by the distribution of rainfall within the season. So pervasive are the implications of climatic variability for human welfare (Stern \& Easterling, 1999) that a wide variety of measures have been suggested for adaptation including water conservation (Boland, 1997) and changes to agricultural practices (Adams et al., 1990).

Definitions of what constitutes a growing season abound (Stern, Dennett, \& Dale, 1982) but in the semi-arid tropics this consists of the period when soil water, resulting mainly from rain, is freely available to the crop. In 
general the start and end of the rains characterize the growing season. In the tropics though, to define an event to mark the start and end dates is not easy due to the intermittent and patchy nature of tropical rainfall (Stern et al., 1982). Changes in the length of growing season can result from changes in rainfall patterns due to climate change. There is a growing body of evidence to suggest that the growing season is gradually getting shorter in some tropical semi-arid areas (Kihupi et al., 2007).

Anthropogenic factors such as extensive land clearance for agriculture, overgrazing and burning of fossil fuels have been linked with climate change (McCarthy, Canziani, Leary, Dokken, \& White, 2001). For thousands of years, human activities have transformed the earth's surface by converting natural forests, savannas and steppes into agricultural lands and substantially modifying others with significant consequences for land cover, biodiversity, soil condition and water and sediment flows (Lambin, Geist, \& Lepers, 2003). For instance, it has been reported that over the past four decades there has been a notable change in land uses in the Maasai Steppe of northern Tanzania, especially from small-scale subsistence cultivation to extensive large-scale farming (Mwalyosi, 1992) with agriculture as a whole registering a fivefold increase between 1984 and 2000 (Msoffe et al., 2011). Similar trends have been reported elsewhere. On the slopes of Mount Kilimanjaro for example the area under cultivation increased from $54 \%$ in 1973 to 62 and 63\% in 1984 and 2000, respectively (Misana, Sokoni, \& Mbonile, 2012). Globally, it has been shown that climate change will expand suitable cropland particularly in the northern high latitudes while the converse is true for most sensitive regions in the tropics where also the suitability for multiple cropping is projected to decrease (Zabel, Putzenlechner, \& Mauser, 2014).

Understanding the nature and extent of changes of growing season characteristics as well as assessing the driving forces behind such changes is essential for policy and other strategies aimed at improving small-scale agricultural production. This paper presents the findings of a study that was undertaken to analyze the trend of growing season characteristics in the semi-arid part of Arusha District which forms part of the Maasai Steppe in northern Tanzania and their implications for sustainable agricultural development specifically for small-scale farmers.

\section{Materials and Methods}

\subsection{The Study Area}

Oljoro Ward, the study area is within Arusha District and located about 15 kilometres south west of Arusha city at an altitude ranging from 1,375-1,400 $\mathrm{m}$ amsl (Figure 1). It lies at the foot of Mount Meru which is an extinct volcano and hence the geology of the area is related to volcanic rocks and ashes. The climate of the area can be described as semi-arid with a mean annual rainfall of $818 \mathrm{~mm}$. Arusha District has a bimodal rainfall pattern with the short rains (vuli) starting early November and ending early January. The long rains (masika) start around mid March and end late May (Kihupi et al., 2007). Figure 2 depicts the two peaks in terms of the probability of having a given amount of rainfall in particular the 20,50 and 80 percent probabilities of exceedance representing the wet, normal and dry year respectively which is important for planning purposes. Long rains are more reliable and main food crops including maize and beans are grown during this season which lasts on average 100 days (Kihupi et al., 2007). The mean temperature of the area is $20{ }^{\circ} \mathrm{C}$ with lowest temperature $\left(17{ }^{\circ} \mathrm{C}\right)$ occurring in July and highest temperature $\left(22^{\circ} \mathrm{C}\right)$ occurring in March. Winds are moderate not exceeding $4 \mathrm{~m} / \mathrm{s}$ on average throughout the year except in October when they exceed $5 \mathrm{~m} / \mathrm{s}$ and thus slightly strong. Mean annual relative humidity is moderately high $(>60 \%)$ especially so during the short and long rainy seasons. The area is drained by a seasonal stream Engare Olmotoni which carries plenty of water that causes flooding to the lowlands during the rainy season. 


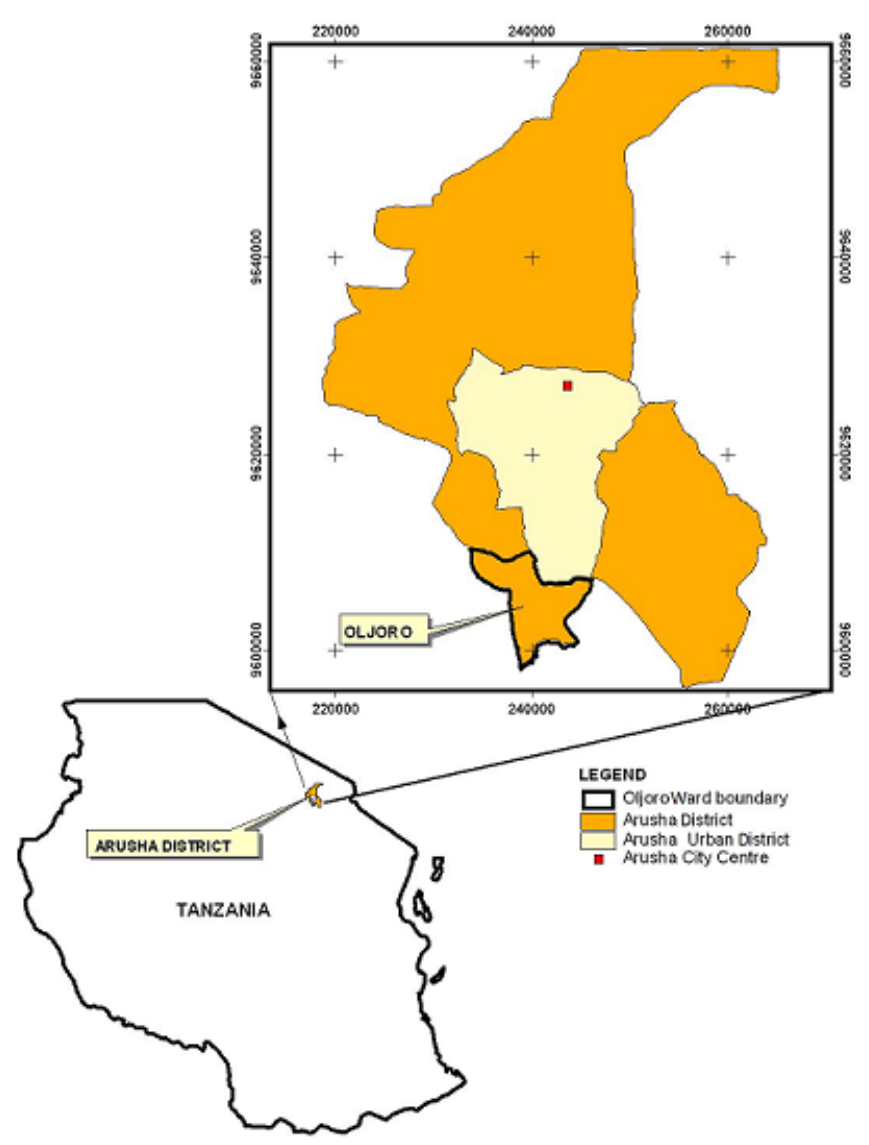

Figure 1. Map of the study area with the administrative boundaries of Arusha District

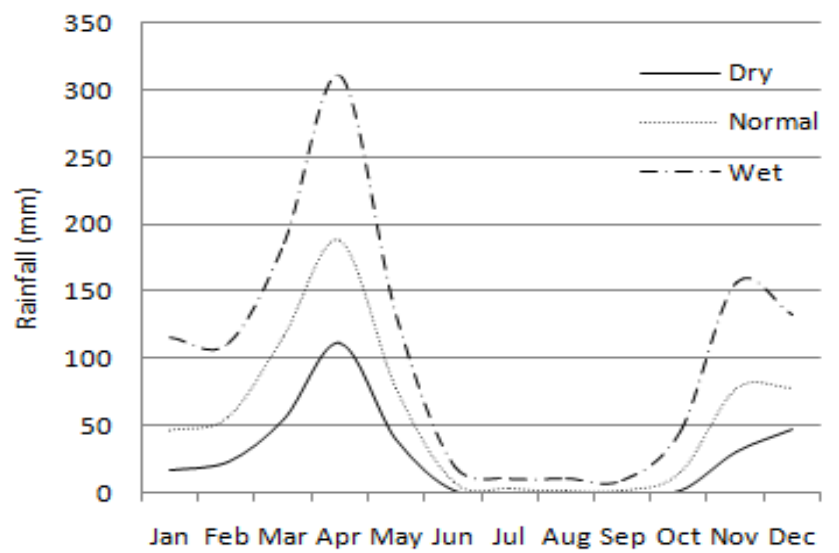

Figure 2. Expected rainfall amounts for each month in Arusha District with a 20, 50, and 80 percent probability of exceedance representing a wet, normal and dry year respectively

\subsection{Assessment of Growing Season Characteristics}

Fifty two years of climatic data for Arusha airport in Arusha District were used to characterize the growing season of the study area. The definition of start and end of growing season given by Stern et al. (1982) and adapted by Kingamkono, Kihupi, and Dihenga (1994) was adopted in this study. The length of the growing season was taken as the duration between the onset and cessation dates of the growing season. Seasonal rainfall was computed from the daily records between the start and end dates of the season for each year. The numbers of wet days as well as extreme events within the growing season were determined for each year of record. This was done for each of the two seasons, vuli and masika. INSTAT plus (v3.6) software (Stern, Rijks, Dale, \& Knock, 2006) was used for the climatic data analysis and manipulation while Microsoft Excel spreadsheet was used for 
other statistical computations and graphics. Results of computations specifically for the onset and cessation dates were crosschecked physically by viewing the raw data using the "Display daily data" command in INSTAT and adjustments made where necessary.

\subsection{Trend Analysis of Growing Season Characteristics and other Meteorological Variables}

Linear trend lines were fitted to the data for onset date, cessation date, and seasonal rainfall total as well as total annual rainfall, number of rainy (wet) days within the growing season and length of the growing season. Long dry spells within the growing season were also analyzed for various temporal periods to see if there was any trend. Other meteorological variables such as temperature (maximum and minimum) as well as wind, humidity and reference evapotranspiration $\left(\mathrm{ET}_{\mathrm{o}}\right.$ ) were also analyzed for trend.

The Mann-Kendall test was used to test for significance of trends of growing season characteristics including trends of other meteorological variables. It is a widely used statistical test for the analysis of trend in climatologic and hydrologic time series (Onoz \& Bayazit, 2012). The Man-Kendall test is less sensitive to outliers and has the capability to detect both linear and non-linear trends (P. Legendre \& L. F. Legendre, 2012). It has been used in related studies in sub-Saharan Africa (Mazvimavi, 2010; Hadgu, Tesfaye, Mamo, \& Kassa, 2013).

\section{Results and Discussion}

\subsection{Rainfall Regime}

Cumulative mean daily rainfall was computed from the 52-year record and plotted against day number (Figure 3). Apart from depicting the type of rainfall regime, the plot is useful in deriving the earliest possible start and end dates which are inputs in the INSTAT programme for the determination of rainfall onset and cessation dates. The figure clearly shows that Arusha District has a bimodal rainfall regime although the end of the short rains is not as sharply defined, at times merging with the start of the long rains.

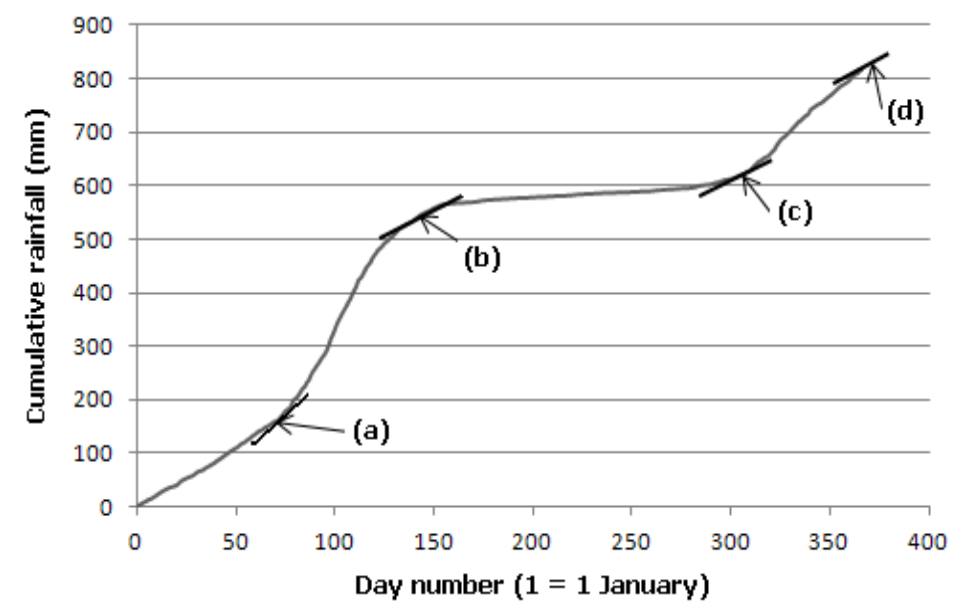

Figure 3. Cumulative mean daily annual rainfall for Arusha District with points of maximum curvature representing mean (a) onset of long rains, (b) cessation of long rains, (c) onset of short rains, (d) cessation of short rains

\subsection{Mann-Kendall Trend Test Statistics}

Table 1 shows the Mann-Kendall trend test statistics for the various growing season characteristics and other meteorological variables. Except for the relative humidity and reference evapotraspiration, the significance of the results is similar to the one obtained by simple regression analysis using the correlation coefficient, $r$ (Clarke, 1976). The correlation coefficient was negative and significant at the $5 \%$ level for relative humidity whereas that for the reference evapotranspiration was positive and significant at the $0.1 \%$ level. So in this case there is not much difference between the two statistical tests of significance implying that the data were to a large extent independent and normally distributed. 
Table 1. Trend of growing season characteristics for long rains and other meteorological variables for Arusha District

\begin{tabular}{llll}
\hline Time series & Test Z & Significance & Sen's slope \\
\hline Onset dates & 2.95 & $* *$ & 0.547 \\
Cessation dates & -1.22 & $\mathrm{~ns}$ & -0.130 \\
Growing season length & -3.36 & $* * *$ & -0.634 \\
Seasonal rainfall & -1.86 & $\mathrm{~ns}$ & -2.323 \\
Annual rainfall & -1.70 & $\mathrm{~ns}$ & -3.674 \\
Wet days & -2.87 & $* *$ & -0.333 \\
Minimum temperature & 6.02 & $* * *$ & 0.027 \\
Maximum temperature & 3.03 & $* *$ & 0.018 \\
Mean temperature & 5.52 & $* * *$ & 0.022 \\
Surface wind speed & 3.96 & $* * *$ & 0.049 \\
Relative humidity & -1.96 & $\mathrm{~ns}$ & -0.074 \\
Reference ET & 2.36 & $*$ & 0.010
\end{tabular}

Note. $*$ statistically significant at 0.05 probability level; ** statistically significant at 0.01 probability level; *** statistically significant at 0.001 probability level; ns non significant.

\subsection{Growing Season Characteristics}

\subsubsection{Long Rains}

Figures 4 (a) and (b) show the trend of rainfall onset and cessation dates respectively for Arusha District during the long rainy season. The trend of rainfall onset is significant at the $1 \%$ level but that of the rainfall cessation is not implying that there is much less variation in the cessation date compared to the onset date. These findings are consistent with those of other researchers (Alusa \& Mushi, 1974; Kihupi et al., 2007). The trend of growing season length (Figure 5a) is negative and significant at the $0.1 \%$ level. It appears that long rains in Arusha District are progressively starting later and ending earlier than before, resulting in a shorter growing season. This trend has also been shown for some areas in Arusha Region specifically Arumeru District (Kihupi et al., 2007).

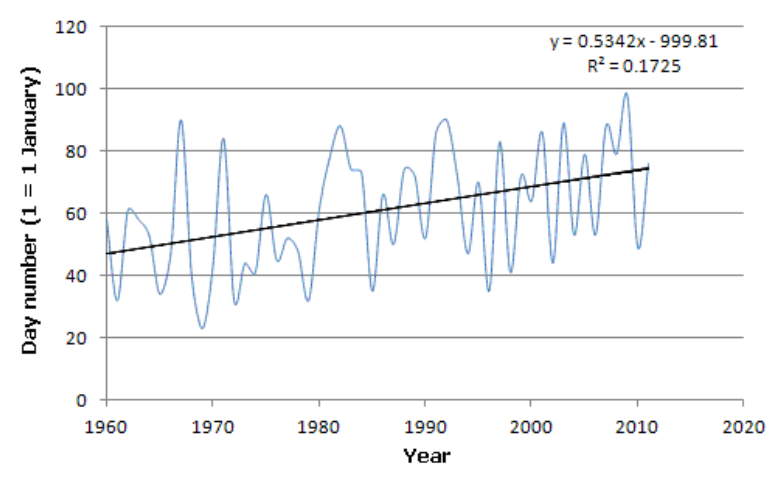

(a)

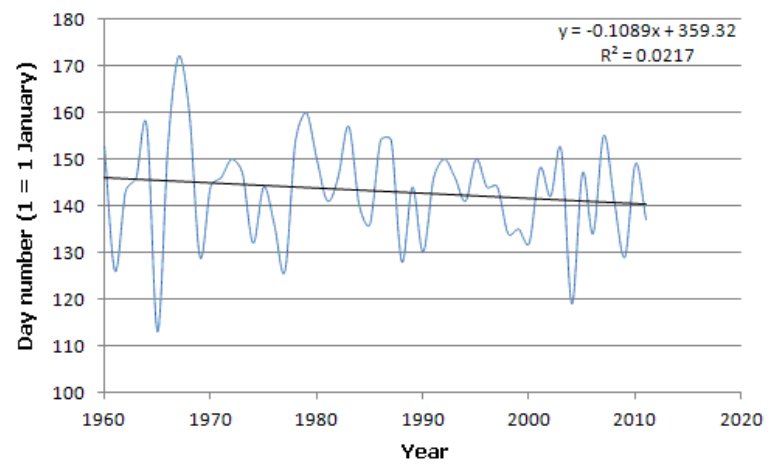

(b)

Figure 4. Trend of rainfall onset (a) and cessation (b) dates for Arusha District (long rains)

This would seem to indicate changes in the rainfall pattern. Whether or not the changes in growing season characteristics observed in Arusha District are indicative of long-term climatic change is open to debate. There is no single or unified theory explaining the long-term changes in the earth's climate. On the other hand, there are numerous potential human sources of "short-term" climatic change such as extensive land clearing, overgrazing and the burning of fossil fuels (McCarthy et al., 2001). 


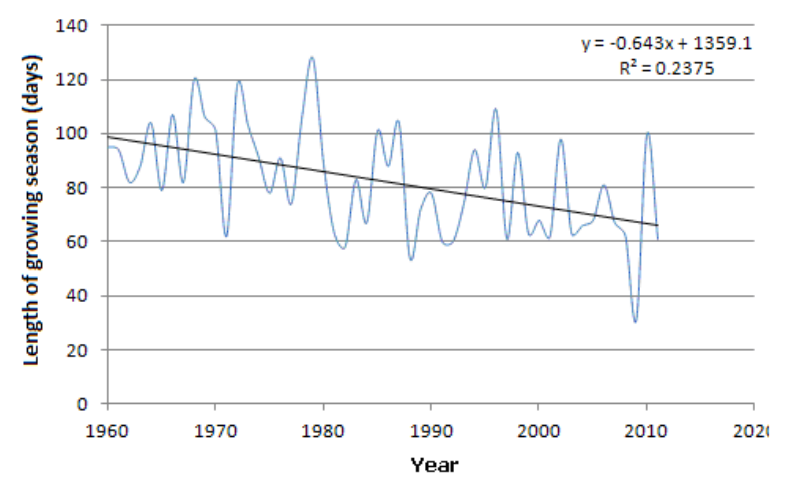

(a)

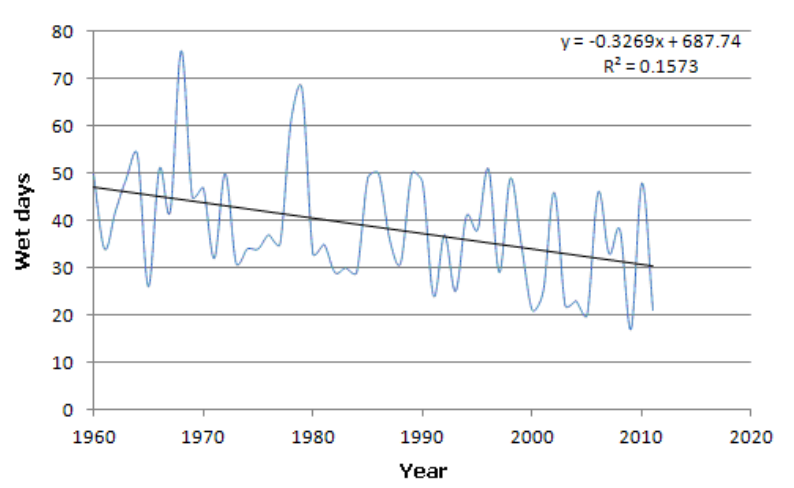

(b)

Figure 5. Trend of growing season length (days) (a) and number of wet days (b) for Arusha District (long rains)

The trend of number of wet days within the growing season (long rains) in Arusha District is negative and significant at the $1 \%$ level (Figure 5b). In other words the severity of dry spells in the area is getting more intense. This situation has implications for the way farmers make decisions in the choice of crops and crop varieties to grow. A compromise would seem to be a choice between more drought resistant crop varieties and supplementary irrigation. Considerable work has been done on drought tolerance improvement in crop plants as reviewed by Cattivelli et al. (2008). Although plant breeders have made ample progress through conventional breeding in developing drought tolerant lines/cultivars of some selected crops, the approach is, in fact, highly time-consuming and labour- and cost-intensive (Ashraf, 2010). Hu and Xiong (2014) provide a brief review on the progress in genetic, genomic, and molecular studies of drought resistance in major crops.

Seasonal rainfall as well as total annual rainfall in Arusha District appear to be decreasing with time (Figures 6a, and $6 \mathrm{~b}$ ) although the trend is not significant. A similar trend has been noted elsewhere specifically in the Usangu Plains in Tanzania (Kihupi et al., 2007) where even the quality of the growing season appears to be getting poorer. This lends credence to widely held views that the gap between available water supply and water demand is increasing in many parts of the world and has serious implications for the options open to the people in the area to adapt. Under such circumstances, the main coping strategy would appear to be irrigation. However sources of fresh water for such an undertaking are limited and would require making irrigation more effective and promoting technologies that enable farmers to get more crops per drop, i.e. improving water productivity (Postel, Polak, Gonzales, \& Keller, 2001). Other options aimed at improving the soil moisture regimes are pertinent to issues of water productivity. These include in-situ rainwater harvesting (Hatibu \& Mahoo, 1999; Vohland \& Barry, 2009) and agricultural polymers (Jhurry, 1997). Water absorbing polymers or hydrogels have been tried with varying success, albeit on small scale agriculture. For instance the work of Al-Harbi et al. (1994) on the effect of a gel-forming conditioner on the growth pf tomato seedlings in a greenhouse showed significant improvement in plant growth which was attributed to increased water availability. In a laboratory study to investigate the effect of a gel-forming soil conditioner on hydraulic properties of a sandy soil, it was revealed that the addition of the soil conditioner improved the soil's hydraulic properties (Al-Darby, 1996). However the water storage properties of these soil conditioners are significantly affected by the nature and concentrations of dissolved salts in irrigation waters (Johnson, 1984). 


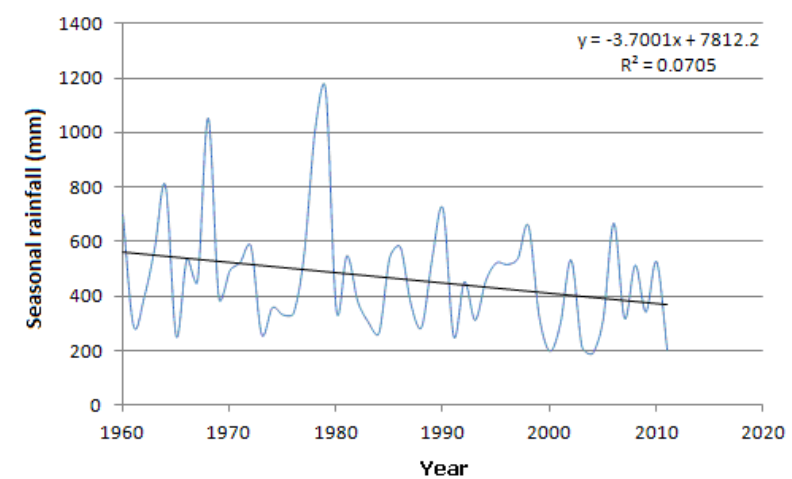

(a)

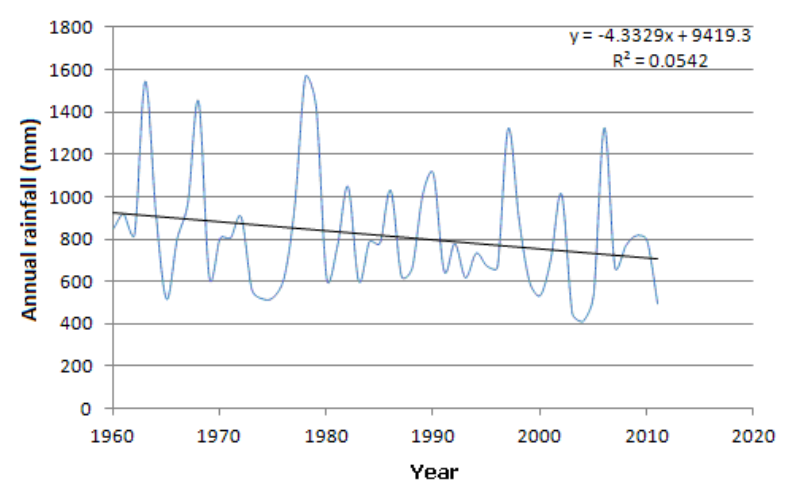

(b)

Figure 6. Trend of seasonal rainfall (a) and annual rainfall (b) for Arusha District (long rains)

There is also a discernible increase in the occurrence of long dry spells with time during the growing season (Figure 7). The probability of having dry spells of 7 days or more during the growing season was much less in previous years than it is presently. However there is no evidence to suggest that extreme climatic events in the area are on the increase. This further emphasizes the need for proper choice of crops or crop varieties that can withstand drought or the judicial use of water for irrigation to mitigate the effects of such spells.

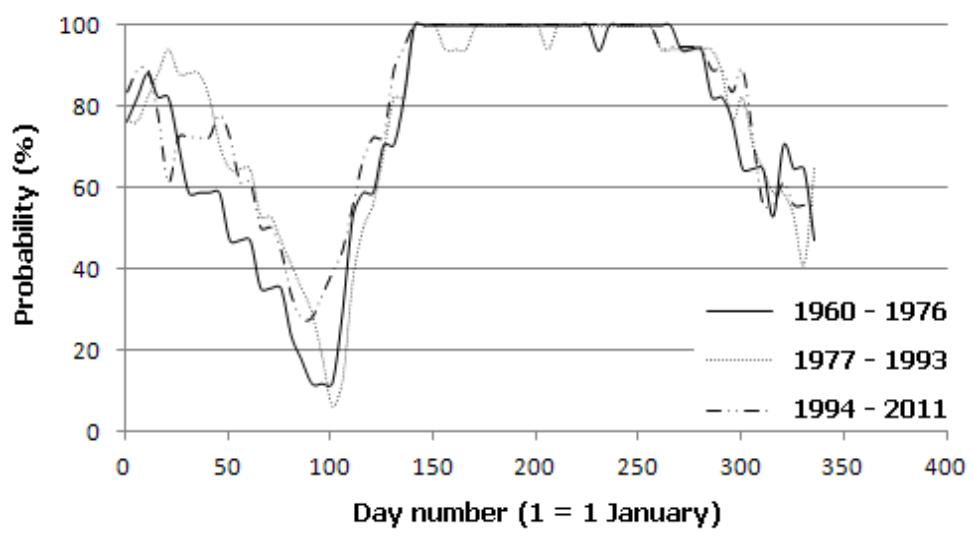

Figure 7. Trend of probability of a 7-day dry spell within a 30-day period following the date indicated on the horizontal axis for Arusha District for the respective temporal periods

\subsubsection{Short Rains}

Similar trends exist for the short rains in Arusha District albeit not as pronounced. Nonetheless short rains are unreliable and non existent in some years. In recent years (since 1995) short rains have completely failed in five seasons compared to previous years where only one failure was recorded. So the indication is that apart from being unreliable in terms of the characteristics presented above, short rains are getting even "shorter" as time progresses. This has far-reaching implications for water resources in the area and elsewhere as observable evidence shows that fresh water is a dwindling resource. Hydrological studies in Tanzania have shown a decreasing trend in the dry season flows of some of the perennial rivers such as those in the Rufiji basin (Tarimo et al., 2002).

\subsection{Other Meteorological Variables}

Although winds in Arusha District appear to be moderate $(2-5 \mathrm{~m} / \mathrm{s})$, there has been a significant $(\mathrm{p}<0.01)$ increase in surface wind speeds over time (Figure 8a). This could be attributed to anthropogenic factors such as deforestation and unsustainable agricultural practices in the area. It is also interesting to note the nature of the trend as it appears to be nonlinear. Prior to early 1990s the trend was downward but there was an abrupt change thereafter. A plausible explanation could be that around that time there was a significant change in land cover as a result of changes in land use in the area. This is supported by findings of other researchers in and around the 
study area such as Mwalyosi (1992) and Msoffe et al. (2011) who reported extensive expansion of agricultural land in the Maasai Steppe and on the slopes of Mount Kilimanjaro (Misana et al., 2012) at the expense of the natural vegetation around that time. This is also reflected in the computations of the reference evapotranspiration for the area (Figure 10a) for which the aerodynamic term in the Penman-Monteith equation which was used for the calculation of $\mathrm{ET}_{\mathrm{o}}$ as recommended by FAO (Allen, Pereira, Raes \& Smith, 1998) appears to have a much higher contribution than the radiation term especially so during the last two decades. Population pressure could be another driving force as reported by Msoffe et al. (2011).
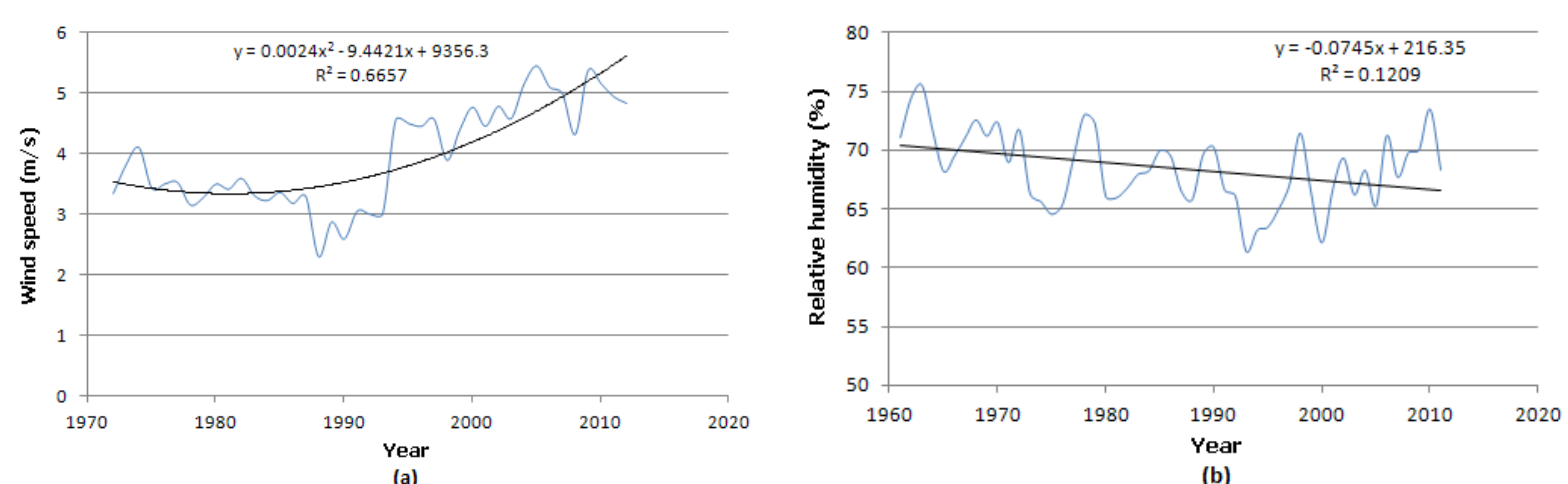

Figure 8. Trend (polynomial) of mean annual wind speed (a) and mean annual relative humidity

(b) for Arusha District

On the other hand, the trend of mean annual relative humidity is negative but not significant (Figure 8b). This is a reflection of the rainfall pattern as previously illustrated.

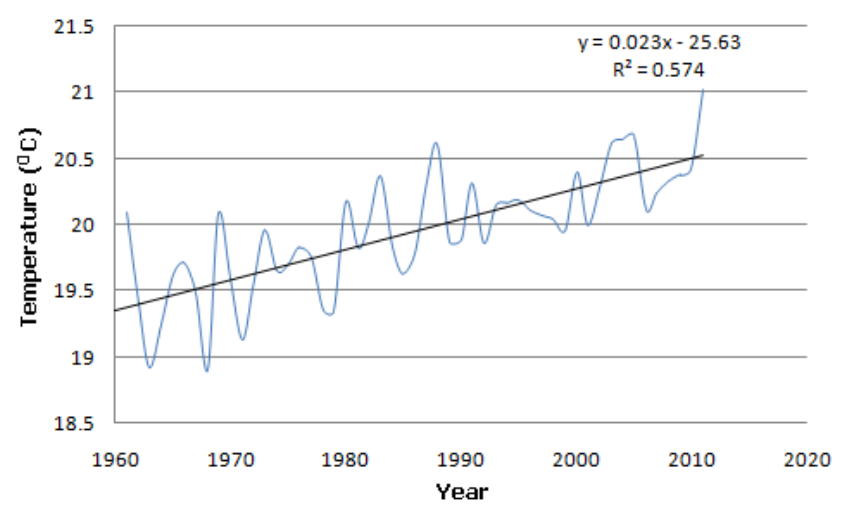

Figure 9. Trend of mean annual temperature for Arusha District

The trend of the mean annual temperature for Arusha District is positive and significant at the $0.1 \%$ level (Figure 9). This is consistent with many studies on global warming (Intergovernmental Panel on Climate Change [IPCC], 2007). In the case of Arusha District, the mean minimum temperature appears to increase at a higher rate than the mean maximum temperature. This has serious implications for agricultural crops which may currently be near their limit of heat tolerance. Coupled with decreasing water availability due to changes in rainfall patterns, global warming will further enhance crop water requirements in the area due to increased atmospheric evaporative demands (Figure 10a). 

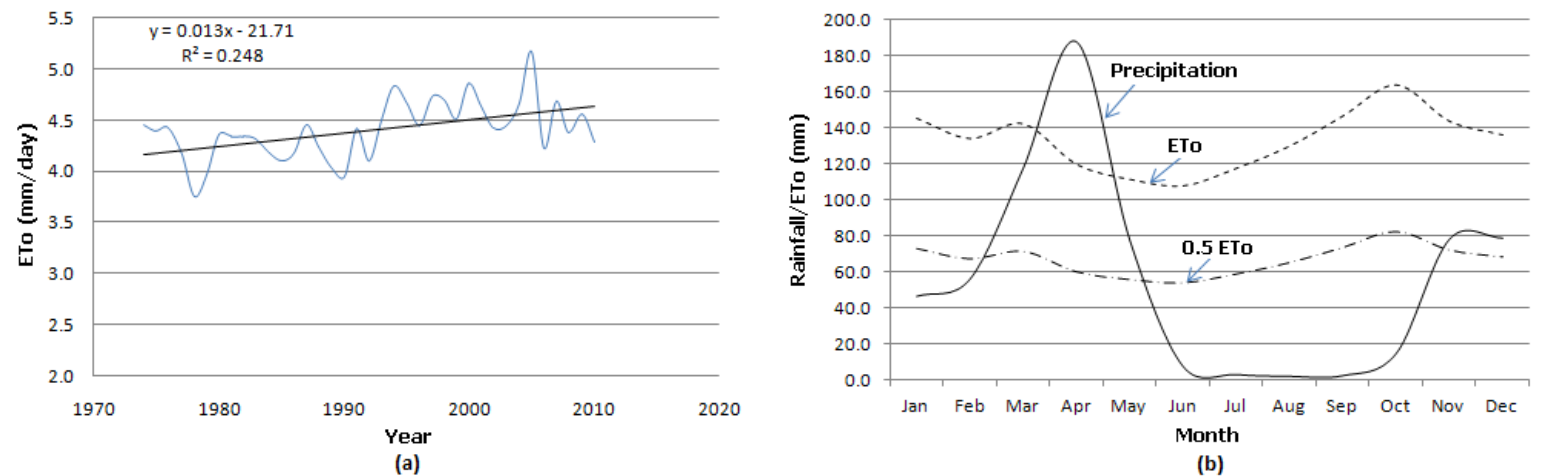

(b)

Figure 10. Trend of mean annual reference evapotranspiration $\left(\mathrm{ET}_{\mathrm{o}}\right)(\mathrm{a})$ and a comparison of mean monthly $\mathrm{ET}_{\mathrm{o}}$ and precipitation (b) for Arusha District

The atmospheric evaporative demand represented by the reference evapotranspiration is showing a rising trend (Figure 10a) which is significant at the $5 \%$ level. The humid period (when precipitation is above $\mathrm{ET}_{\mathrm{o}}$ ) in Arusha District is very short (Figure 10b) and only spans two months (March and April). This implies that full crop water requirements during the main growing season (long rains) are not met for most of the crops. Supplementary irrigation during this period is required to ensure full production as exact timing of the start of the season may be tricky. Outside the main growing season, no rainfed agricultural production is viable.

\section{Conclusion}

The climate of Arusha District and Oljoro in particular is changing. Changes in land use/cover in and around the study area in the 1970s through 1990s due to expansion of agricultural land and population pressure would seem to have fuelled the observed changes in the growing season characteristics. This does not augur well for rainfed agriculture and thus judicial use of scarce water resources including rainwater harvesting would seem to be a viable option for sustainable agricultural production.

\section{Acknowledgements}

This work is part of an on-going research project under the innovative Agricultural Research Initiative (iAGRI)), a Feed the Future Project and the authors are grateful to USAID for the financial support. The authors are also grateful to the Tanzania Meteorological Agency for the climatic data used in this study.

\section{References}

Adams, R. M., Rosenzweig, C., Peart, R. M., Ritchie, J. T., McCarl, B. A., Glyer, J. D., ... Allen, L. H. Jr. (1990). Global climate change and US agriculture. Nature, 345, 219-224. http://dx.doi.org/10.1038/345219a0

Al-Darby, A. M. (1996). The hydraulic properties of a sandy soil treated with gel-forming soil conditioner. Soil Technology, 9(1-2), 15-28. http://dx.doi.org/10.1016/0933-3630(95)00030-5

Al-Harbi, A. R., Al-Omran, A. M., Wahdan, H., \& Shalaby, A. A. (1994). Impact of irrigation regime and addition of a soil conditioner on tomato seedling growth. Arid Soil Research and Rehabilitation, 8(3), 285-290. http://dx.doi.org/10.1080/15324989409381403

Allen, R. G., Pereira, L. S., Raes, D., \& Smith, M. (1998). Guidelines for Computing Crop Water Requirements. Irrigation and Drainage Paper 56. Rome, Italy: United Nations Food and Agriculture Organization.

Alusa, A. L., \& Mushi, M. T. (1974). A study of the onset, duration and cessation of the rains in East Africa. Proceedings of the International Tropical Meteorology Meeting (pp. 133-140). Boston, Mass: American Meteorological Society.

Ashraf, M. (2010). Inducing drought tolerance in plants: Recent advances. Biotechnol Adv., 28(1), 169-183. http://dx.doi.org/10.1016/j.biotechadv.2009.11.005

Boland, J. J. (1997). Assessing urban water use and the role of water conservation measures under climate uncertainty. Climatic Change, 37(1), 157-176.

Cattivelli, L., Rizza, F., Badeck, F., Mazzucotelli, E., Mastrangelo, A. M., Francia, E., ... Stanca, A. M. (2008). Drought tolerance improvement in crop plants: An integrated view from breeding to genomics. Field Crops Research, 105(1-2), 1-14. http://dx.doi.org/10.1016/j.fcr.2007.07.004 
Clarke, G. M. (1976). Statistics and experimental design. London, UK: Edward Arnold.

Hadgu, G., Tesfaye, K., Mamo, G., \& Kassa, B. (2013). Trend and variability of rainfall in Tigray, Northern Ethiopia: Analysis of meteorological data and farmers' perception. Academia Journal of Agricultural Research, 1, 88-100.

Hatibu, N., \& Mahoo, H. (1999). Rainwater harvesting technologies for agricultural production: A case for Dodoma, Tanzania. In P. G. Kaumbutho \& T. E. Simalenga (Eds.), Conservation tillage with animal traction. A resource book of the Animal Traction Network for Eastern and Southern Africa (ATNESA) (pp. 161-171). Harare, Zimbabwe: ATNESA.

Hu, H., \& Xiong, L. (2014). Genetic engineering and breeding of drought-resistant crops. Annual Review of Plant Biology, 65, 715-741. http://dx.doi.org/10.1146/annurev-arplant-050213-040000

Intergovernmental Panel on Climate Change (IPCC). (2007). Fourth Assessment Report (Chapter 3). Retrieved from http://www.ipcc.ch/pdf/assessment-report/ar4/wg1/ar4-wg1-chapter3.pdf

Jhurry, D. (1997). Agricultural polymers. AMAS (pp. 109-113). Réduit, Mauritius: Food and Agricultural Research Council. Retrieved from http://www.uom.ac.mu/Polymer/files/downloads/articles/uom18.pdf

Johnson, M. S. (1984). Effect of soluble salts on water absorption by gel-forming soil conditioners. Journal of the Science of Food and Agriculture, 35(10), 1063-1066. http://dx.doi.org/10.1002/jsfa.2740351004

Kanemasu, E. T., Stewart, J. I., Van Donk, S. J., \& Virmani, S. M. (1990). Agroclimatic approaches for improving agricultural productivity in semiarid tropics. In R. P. Singh, J. F. Parr \& B. A. Stewart (Eds.), Advances in Soil Science (Vol. 13), Dryland Agriculture, Strategies for sustainability (pp. 273-309). New York, NY: Springer-Verlag. http://dx.doi.org/10.1007/978-1-4613-8982-8_14

Kihupi, N. I., Tarimo, A. K. P. R., \& Dihenga, H. O. (2007). Spatial and temporal variation of growing season characteristics in Tanzania. Journal of the Geographical Association of Tanzania, 32, 33-49.

Kingamkono, R. M. L., Kihupi, N. I., \& Dihenga, H. O. (1994). Length of growing season vis-a-vis rainfall distribution in Tanzania. In C. Lungu (Ed.), Proceedings of the $5^{\text {th }}$ Annual Scientific Conference of SADC-Land \& Water Management Research Programme (pp. 141-155). Harare, Zimbabwe: SADC-L\&WMRP.

Lambin, E. F., Geist, H. J., \& Lepers, E. (2003). Dynamics of land-use and land-cover change in tropical regions. Annu. Rev. Environ. Resour., 28, 205-241. http://dx.doi.org/10.1146/annurev.energy.28.050302.105459

Legendre, P., \& Legendre, L. F. (2012). Numerical ecology (Vol. 24). Amsterdam: Elsevier. http://dx.doi.org/10.1016/B978-0-444-53868-0.50003-4

Mazvimavi, D. (2010). Investigating changes over time of annual rainfall in Zimbabwe. Hydrology and Earth System Sciences, 14, 2671-2679. http://dx.doi.org/10.5194/hess-14-2671-2010

McCarthy, J. J., Canziani, O. F., Leary, N. A., Dokken, D. J., \& White, K. S. (Eds.). (2001). Climate change 2001: Impacts, Adaptation and Vulnerability. Contribution of Working Group II to the Third Assessment Report of the Intergovernmental Panel on Climate Change (pp. 75-104). Cambridge, UK: Cambridge University Press.

Misana, S. B., Sokoni, C., \& Mbonile, M. J. (2012). Land-use/cover changes and their drivers on the slopes of Mount Kilimanjaro, Tanzania. Journal of Geography and Regional Planning, 5(6), 151-164. http://dx.doi.org/10.5897/JGRP11.050

Msoffe, F. U., Kifugo, S. C., Said, M. Y., Ole Neselle, M., Van Gardingen, P., Reid, R. S., ... de Leeuw, J. (2011). Drivers and impacts of land-use change in the Maasai Steppe of northern Tanzania: an ecological, social and political analysis. Journal of Land Use Science, 6(4), 261-281. http://dx.doi.org/10.1080/1747423X.2010.511682

Mwalyosi, R. B. B. (1992). Land use changes and resource degradation in South West Masailand, Tanzania. Environmental Conservation, 19, 145-152. http://dx.doi.org/10.1017/S0376892900030629

O’Brien, K., \& Vogel, C. (Eds.). (2003). Coping with climate variability. The use of seasonal climate forecasts in southern Africa. Aldershot: Ashgate.

Onoz, B., \& Bayazit, M. (2012). The power of statistical tests for trend detection. Turkish Journal of Engineering and Environmental Sciences, 27, 247-251.

Postel, S., Polak, P., Gonzales, F., \& Keller, J. (2001). Drip irrigation for small farmers: A new initiative to 
alleviate hunger and poverty. Water International, 26(1), 3-13. http://dx.doi.org/10.1080/02508060108686882

Stern, P. C., \& Easterling, W. E. (Eds.). (1999). Making climate forecasts matter. Washington, DC: National Academy Press.

Stern, R. D., Dennett, M. D., \& Dale, I. C. (1982). Analysis of daily rainfall measurements to give agronomically useful results. I. Direct methods. Experimental Agriculture, 18, 233-236. http://dx.doi.org/10.1017/S001447970001379X

Stern, R., Rijks, D., Dale, I., \& Knock, J. (2006). INSTAT (Interactive Statistics) Climatic Guide. Statistical Services Centre, University of Reading, UK.

Tarimo, A. K. P. R., Kihupi, N. I., Dihenga, H. O., Mbilinyi, B., Mwalusaka, E. M., \& Mkoga, Z. J. (2002). Effects of land use/cover changes in the uplands of a river catchment to the lowlands: A case study of Chimala River catchment in the Usangu Plains. In L. D. B. Kinabo, R. E. Malimbwi, J. G. Lyimo-Macha \& P. J. Makungu (Eds.), Proceedings of the First Collaborative Research Workshop on Food Security (pp. 110-119). Morogoro, Tanzania: TARP II-SUA Project.

Unganai, L. S. (1993). Chronology of droughts in southern Africa, the impacts and future management options. In M. Kronen (Ed.), Proceedings of the $4^{\text {th }}$ Annual Scientific Conference of SADC-Land \& Water Management Research Programme (pp. 10-19). Windhoek, Namibia: SADC-L\&WMRP.

Vohland, K., \& Barry, B. (2009). A review of in situ rainwater harvesting (RWH) practices modifying landscape functions in Afrcan drylands. Agriculture, Ecosystems \& Environment, 131(3-4), 119-127. http://dx.doi.org/10.1016/j.agee.2009.01.010

Zabel, F., Putzenlechner, B., \& Mauser, W. (2014). Global agricultural land resources - A high resolution suitability evaluation and its perspectives until 2100 under climate change conditions. PLOS ONE, 9(9). http://dx.doi.org/10.1371/journal.pone.0107522

\section{Copyrights}

Copyright for this article is retained by the author(s), with first publication rights granted to the journal.

This is an open-access article distributed under the terms and conditions of the Creative Commons Attribution license (http://creativecommons.org/licenses/by/3.0/). 